\title{
Molecular analysis of genetic stability in long-term micropropagated shoots of banana using RAPD and ISSR markers
}

\author{
Venkatachalam Lakshmanan \\ Plant Cell Biotechnology Department \\ Central Food Technological Research Institute \\ Mysore - 570 020, India \\ Tel: 918212516502 \\ Fax: 918212517233 \\ E-mail: genevenki@yahoo.com
}

\author{
Sreedhar Reddampalli Venkataramareddy \\ Plant Cell Biotechnology Department \\ Central Food Technological Research Institute \\ Mysore - 570 020, India \\ Tel: 918212516502 \\ Fax: 918212517233 \\ E-mail: rvsree@rediffmail.com
}

\author{
Bhagyalakshmi Neelwarne* \\ Plant Cell Biotechnology Department \\ Central Food Technological Research Institute \\ Mysore - 570 020, India \\ Tel: 918212516502 \\ Fax: 918212517233 \\ E-mail: blakshmi_1999@yahoo.com
}

Financial support: Junior and Senior Research Fellowship from the Council of Scientific and Industrial Research, India.

Keywords: Growth regulators, Musa, protocol, shoot cultures, somaclonal variation.

\author{
Abbreviations: $\quad$ AS: Adenine Sulphate \\ BAP: 6-Benzylaminopurine \\ ISSR: Inter Simple Sequence Repeats \\ Kn: Kinetin \\ MS: Murashige \& Skoog \\ NR: Nanjanagudu Rasabale \\ RAPD: Random Amplified Polymorphic DNA
}

A large number of micropropagated plantlets of banana, Musa acuminata var. Nanjanagudu Rasabale (NR), that were developed from axillary shoot bud explants over 10 years ago were screened for genetic variation, if any, using RAPD (Random Amplified Polymorphic DNA) and ISSR (Inter-Simple Sequence Repeats) markers. Of the 4000 in vitro plantlets, 11 were used for screening that involved shoot cultures with distinct variation in morphological characteristics (morphotypes). Similarly, the mother maintained in the field was also subjected for genetic analysis. Out of the 50 RAPD and 25 ISSR primers screened, 30 RAPD and 5 ISSR primers produced totally 424 clear, distinct and reproducible band classes resulting in a total of 5088 bands where the banding patterns for each primer was highly uniform and comparable to the field-grown mother clone from which the cultures had been established. These results indicate that the micropropagation protocol developed by us for rapid in vitro multiplication is appropriate and applicable for clonal propagation of banana var. NR over a long period. This is the first report on the use of genetic markers to establish genetic fidelity of long-term micropropagated banana using RAPD and ISSR.

Banana belongs to the genus Musa and is the most important of the tropical fruits accounting for the world production of 40 million tonnes (FAO, 2004). Most of the edible cultivars of banana are sterile triploids or tetraploids, propagated mainly by vegetative means. Tissue culture propagation of banana has gained attention due to its potential to provide genetically uniform, pest- and disease-

*Corresponding author 
free planting materials. Among the delicious dessert bananas, Musa acuminata, var. Nanjanagudu Rasabale (NR) (group "Silk" having genotype AAB) which is grown in Mysore district of Karnataka, India, has very high commercial demand due to its inviting aroma and white fluffy sweet pulp. This variety is highly susceptible to bacterial and viral diseases reducing the area of cultivation to only 5 hectares and hence recently considered as an endangered one.

Propagation of banana through in vitro techniques has been reported by several researchers using different explant sources as well as regeneration pathways (Novak et al. 1989; Bhagyalakshmi and Singh, 1995; Venkatachalam et al. 2006). A very few exogenous hormones and growth regulators have been reported useful for the micropropagation of banana (Novak et al. 1989; Bhagyalakshmi and Singh, 1995) where the sub- and supraoptimal levels of plant growth substances, especially the synthetic ones, have been associated with somaclonal variation (Martin et al. 2006). Even at optimal levels, longterm multiplication often may lead to somaclonal or epigenetic variations in the micropropagated plants questioning the very fidelity of their clonal nature. Therefore, it is necessary to establish genetic uniformity of micropropagated shoots by recent molecular techniques.

Analyses of isozymes patterns of specific enzymes provide a convenient method for detection of genetic changes but they are subjected to ontogenic variations. Such methods have limited applications due to their limited numbers and only those DNA regions coding for soluble proteins can be sampled. Tissue and environment independence in expression of DNA based markers have made them more reliable over morphological and isozyme markers. Among various DNA-based markers, though Restriction Fragment Length Polymorphism (RFLP) can be used for screening genetic stability of tissue cultured plants, the method involves use of expensive enzymes, radioactive labeling and extensive care, therefore, appears unsuitable. Random Amplified Polymorphic DNA (RAPD) and Inter Simple Sequence Repeats (ISSR) markers, on the other hand, require only small amount of DNA sample without involving radioactivity tests and are simpler as well as faster. RAPD has proven to be quite efficient in detecting genetic variations (Williams et al. 1990), even in closely related organisms such as two near isogenic lines (NIL). ISSR technique is also very simple, fast, cost-effective, highly discriminative and reliable (Pradeep et al. 2002). At present, RAPD and ISSR markers have been successfully applied to detect the genetic similarities or dissimilarities in micropropagated material in various plants (Carvalho et al. 2004; Martins et al. 2004; Ramage et al. 2004; Modgil et al. 2005). The study presented here was undertaken to monitor the genetic stability of long term micropropagated shoots of a banana clone using the RAPD and ISSR technique. To our knowledge, this is the first assessment of DNA sequence variation in the long term micropropagules of any Musa species. An in vitro clonal propagation protocol has been developed for efficient multiplication of banana in our lab (Bhagyalakshmi and Singh, 1995) and has been used continuously as an initial step for the production and maintenance of shoot cultures - the latter are often used for other biotechnological studies. The aim of the present study was to assess the impact of the protocol and long term in vitro effects on the induction of somaclonal variation in banana var. NR.

\section{MATERIALS AND METHODS}

\section{Plant material}

A healthy and high yielding banana clone of var. Nanjanagudu Rasabale was collected and maintained as

Table 1. Composition of media used at various stages of micropropagation of NR banana.

\begin{tabular}{|c|c|c|}
\hline Medium & Composition with growth regulators in $\mathrm{mg} \mathrm{I}^{-1}$ & Stages \\
\hline M1 & $\mathrm{MS}^{*}+\mathrm{BAP}(0.2)+$ Sucrose $(3 \%)+$ Gelrite $®(0.2 \%)$ & Meristem culture \\
\hline M2 & $\begin{array}{l}\mathrm{MS}^{*}+\mathrm{BAP}(2)+\mathrm{Kn}(1)+\mathrm{AS}(80)+ \\
\text { Sucrose }(2.5 \%)+\text { Gelrite }(0.25 \%)\end{array}$ & Shoot multiplication \\
\hline M3-A & $\mathrm{MS}^{*}+\mathrm{NAA}(0.5)+$ Sucrose $(2.5 \%)($ Liquid medium $)$ & Elongation and rooting \\
\hline M3-B & $\begin{array}{l}\mathrm{MS}^{*}+\mathrm{NAA}(0.5)+\text { Sucrose }(2.5 \%)+ \\
\quad \operatorname{Agar}(0.8 \%) \text { (Solid medium) }\end{array}$ & $\begin{array}{l}\text { Semi-hardening and further } \\
\text { elongation and rooting }\end{array}$ \\
\hline M4 & $1 / 2 \mathrm{MS}+\operatorname{Agar}(1.6 \%)$ & Hardening \\
\hline
\end{tabular}

* Modified MS where the concentration of ammonium nitrate was reduced to $75 \%$ of original MS medium (Murashige and Skoog, 1962). 


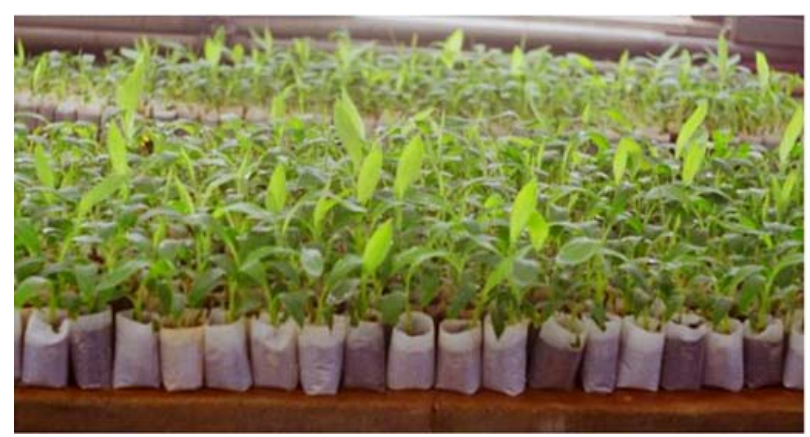

Figure 1. In vitro multiplied plants under hardening. The plantlets were obtained after repeatedly sub-culturing in $\mathrm{M} 2$ medium for 150 times, each after 4 weeks period. Further elongation and rooting were done as mentioned in Table 1 and in section Material and Methods.

mother plant at the back yard of authors' laboratory. The rhizomes of sword suckers were used to excise the meristem and establish shoot cultures as explained earlier (Bhagyalakshmi and Singh, 1995).

\section{Culture medium and incubation conditions}

The aseptic shoot cultures used in the present study were established as reported in an earlier study (Bhagyalakshmi and Singh, 1995) and were maintained on M1 medium containing $3 / 4$ strength Murashige and Skoog (Murashige and Skoog, 1962) basal salts (MS) with additional $1 \mathrm{~g} \mathrm{l}^{-1}$ of potassium nitrate and $1 \mathrm{ml} \mathrm{l}^{-1}$ of vitamin mixture (Novak et al. 1989) supplemented with ascorbic acid (100 $\left.\mathrm{mg} \mathrm{l}^{-1}\right)$, BAP $\left(1 \mathrm{mg} \mathrm{l}^{-1}\right)$, indole butyric acid $\left(0.2 \mathrm{mg} \mathrm{l}^{-1}\right)$ and gelrite ${ }^{B}$ (Sigma, USA) $\left(2.5 \mathrm{~g} \mathrm{l}^{-1}\right)$. The $\mathrm{pH}$ was adjusted to 5.8 before autoclaving at $121^{\circ} \mathrm{C}$ and $15 \mathrm{lbs}$ for $20 \mathrm{~min}$. Cultures were maintained at $25 \pm 1^{\circ} \mathrm{C}$ under a $16 \mathrm{hrs}$ light $\left(320 \mu\right.$ mol.m ${ }^{-2}$ $\left.\mathrm{S}^{-1}\right) / 8 \mathrm{hrs}$ dark photoperiod. The in vitro multiple shoot cultures were established and maintained on M2 medium (Table 1).

\section{Elongation and rooting}

Multiple shoot/buds proliferated from each segment were separated and sub cultured twice with a 4 week interval in liquid medium containing MS basal nutrient with $0.5 \mathrm{mg} \mathrm{l}^{-1}$ NAA for further elongation (M3-A in Table 1). After 8 weeks, individual shoots with $4-5 \mathrm{~cm}$ in length were separated and transferred to solid MS basal medium with $0.5 \mathrm{mg} \mathrm{l}^{-1} \mathrm{NAA}$ (M3-B) for 4 weeks to induce further shoot elongation and root formation. Further hardening before transferring to soil was done by briefly culturing the plantlets in M4 medium (Table 1).

\section{Greenhouse transfer and morphological analysis}

The rooted shoots were washed in running tap water and were planted in polythene bags containing mixture of sand, vermicompost and garden soil in equal proportions. The plants were incubated in a mist chamber maintained at 70$80 \% \mathrm{RH}$ for 3-4 weeks and subsequently maintained in greenhouse for one month (Figure 1) before planting in the field.

\section{Plant material for DNA extraction}

The mother NR plant collected from Nanjanagudu, Karnataka, India was maintained in our department garden and the fresh leaves from this were used as a source of DNA. For testing the long-term effects, the plantlets obtained after repeatedly sub-culturing in M2 medium for 150 times (about 10 years), each after 4 weeks period, were used. Eleven plantlets, including certain morphological variants were chosen from over 4000 micropropagated plantlets (Figure 1) for studying DNA fingerprints.

\section{Preparation of template DNA}

The genomic DNA from the cultures was extracted at the end of last subculture. The DNA was extracted by using the GenElute ${ }^{\mathrm{TM}}$ Plant Genomic DNA Mini prep kit supplied by Sigma (USA). The RNA contamination in all the samples was removed by digesting the extract with 100 RNase-A (100 $\mu \mathrm{g} \mathrm{ml}^{-1}$; Bangalore Genei, India) for $30 \mathrm{~min}$ at $37^{\circ} \mathrm{C}$. Quality and quantity of DNA preparations were checked by standard spectrophotometry and the samples were diluted to a concentration of $25 \mathrm{ng} \mathrm{l}^{-1}$ before use.

\section{DNA amplification}

Initially, optimum PCR conditions for both RAPD and ISSR were standardized with various quantities of template DNA (12.5, 25 and $50 \mathrm{ng})$, dNTPs (100, 200 and $300 \mu \mathrm{M})$ and $\mathrm{MgCl}_{2}(0,1,2$ and $3 \mathrm{mM})$. Later, RAPD amplifications were performed routinely using PCR mixture $(25 \mu 1)$ which contained $25 \mathrm{ng}$ of genomic DNA as template, 1X PCR buffer (Fermentas GMBH, Germany), $200 \mu \mathrm{M}$ dNTPs (Fermentas GMBH, Germany), 1 unit (U) of Taq DNA polymerase (Bangalore Genei, India), $1 \mu \mathrm{M}$ of each primer with various concentrations of $\mathrm{MgCl}_{2}$ (Fermentas $\mathrm{GMBH}$, Germany) (Table 2) depending on the primer (SigmaAldrich, India). PCR was performed at initial denaturation at $93^{\circ} \mathrm{C}$ for $4 \mathrm{~min}$ followed by 40 cycles of $1 \mathrm{~min}$ denaturation at $94^{\circ} \mathrm{C}, 1 \mathrm{~min}$ annealing at $36^{\circ} \mathrm{C}$ and $2 \mathrm{~min}$ extension at $72^{\circ} \mathrm{C}$ with a final extension of $72^{\circ} \mathrm{C}$ for $10 \mathrm{~min}$ using a thermal cycler (Eppendorf Thermal cycler).

In case of ISSR primers, optimal annealing temperature was found to vary according to the base composition of the primers. PCR mixture $(25 \mu \mathrm{l})$ which contained $25 \mathrm{ng}$ of genomic DNA as template, $1 \times$ PCR buffer (Fermentas GMBH, Germany), $200 \mu \mathrm{M}$ dNTPs (Fermentas GMBH, Germany), 1 unit (U) of Taq DNA polymerase (Bangalore Genei, India), $1 \mu \mathrm{M}$ of each primer (Sigma Aldrich, India) with various concentrations of $\mathrm{MgCl}_{2}$ (Table 2) depending on the primer. PCR was performed at initial denaturation of $94^{\circ} \mathrm{C}$ for $4 \mathrm{~min}$ followed by 40 cycles of 1 min denaturation at $94^{\circ} \mathrm{C}, 1 \mathrm{~min}$ annealing at $2^{\circ} \mathrm{C}$ lower than melting point for each primer and $2 \mathrm{~min}$ extension at $72^{\circ} \mathrm{C}$ with a final extension of $72^{\circ} \mathrm{C}$ for 10 min using a thermal cycler. 
Table 2. List of primers, their sequences and size of the amplified fragments generated by 30 RAPD (SI. No. 1-30) and 5 ISSR (SI. No. 31-36) primers.

\begin{tabular}{|c|c|c|c|c|c|c|}
\hline $\begin{array}{l}\text { SI. } \\
\text { No. }\end{array}$ & Primer & $\begin{array}{l}\text { Primer sequence } \\
\qquad\left(5^{\prime}-3^{\prime}\right)\end{array}$ & $\begin{array}{c}\text { G + C } \\
\text { Content } \\
(\%)\end{array}$ & $\begin{array}{c}\mathrm{Mg} \mathrm{Cl}_{2} \\
\text { Concentration } \\
(\mathrm{mM})\end{array}$ & $\begin{array}{c}\text { Number of } \\
\text { scorable bands }\end{array}$ & $\begin{array}{l}\text { Size range } \\
\text { (bp) }\end{array}$ \\
\hline 1 & OPA-04 & AATCGGGCTG & 60 & 2 & 12 & $300-3000$ \\
\hline 2 & OPA-09 & GGGTAACGCC & 70 & 0 & 8 & $400-1800$ \\
\hline 3 & OPA-11 & CAATCGCCGT & 60 & 2 & 18 & $300-3100$ \\
\hline 4 & OPA-14 & CTCGTGCTGG & 70 & 0 & 13 & $200-3000$ \\
\hline 5 & OPA-20 & GTTGCGATCC & 60 & 1 & 14 & $200-2600$ \\
\hline 6 & OPC-01 & TTCGAGCCAG & 60 & 1 & 12 & $280-1800$ \\
\hline 7 & OPC-02 & GTGAGGCGTC & 70 & 2 & 12 & $300-2800$ \\
\hline 8 & OPC-04 & CCGCATCTAC & 60 & 0 & 15 & $220-2000$ \\
\hline 9 & OPC-05 & GATGACCGCC & 70 & 0 & 14 & $320-1900$ \\
\hline 10 & OPC-07 & GTCCCGACGA & 70 & 0 & 16 & $300-2600$ \\
\hline 11 & OPC-08 & TGGACCGGTG & 70 & 1 & 14 & $290-3100$ \\
\hline 12 & OPC-09 & CTCACCGTCC & 70 & 1 & 10 & $480-1800$ \\
\hline 13 & OPC-13 & AAGCCTCGTC & 60 & 0 & 8 & $480-1800$ \\
\hline 14 & OPD-07 & TTGGCACGGG & 70 & 1 & 13 & $380-2500$ \\
\hline 15 & OPD-08 & GTGTGCCCCA & 70 & 0 & 7 & $290-2400$ \\
\hline 16 & OPD-16 & AGGGCGTAAG & 60 & 1 & 14 & $400-2000$ \\
\hline 17 & OPJ-07 & ССTCTCGACA & 60 & 1 & 11 & $300-2000$ \\
\hline 18 & OPJ-08 & CATACCGTGG & 60 & 0 & 6 & $400-3000$ \\
\hline 19 & OPJ-09 & TGAGCCTCAC & 60 & 2 & 8 & $400-2000$ \\
\hline 20 & OPL-14 & TCGTGCGGGT & 70 & 1 & 8 & $1031-2400$ \\
\hline 21 & OPM-12 & CACAGACACC & 60 & 0 & 12 & $300-2600$ \\
\hline 22 & OPM-16 & GTAACCAGCC & 60 & 2 & 18 & $400-2000$ \\
\hline 23 & OPM-20 & AGGTCTTGGG & 60 & 1 & 22 & $320-2000$ \\
\hline 24 & OPM-18 & CACCATCCGT & 60 & 0 & 7 & $400-2000$ \\
\hline 25 & OPN-03 & GGTACTCCCC & 70 & 0 & 18 & $300-2600$ \\
\hline 26 & OPN-04 & GACCGACCCA & 70 & 0 & 12 & $400-2800$ \\
\hline 27 & OPN-06 & GAGACGCACA & 60 & 2 & 11 & $340-2000$ \\
\hline 28 & OPN-09 & TGCCGGCTTG & 70 & 1 & 18 & $240-3000$ \\
\hline
\end{tabular}


Molecular analysis of genetic stability in long-term micropropagated shoots of banana using RAPD and ISSR markers

\begin{tabular}{|r|c|c|c|c|c|c|}
\hline 29 & OPN-10 & ACAACTGGGG & 60 & 1 & 19 & $240-3000$ \\
\hline 30 & OPN-12 & CACAGACACC & 60 & 0 & 7 & $240-2400$ \\
\hline \multicolumn{2}{|c|}{ Total } \\
\hline 31 & UBC-811 & $(\mathrm{GA})_{8} \mathrm{C}$ & - & 0 & 377 & \\
\hline 32 & UBC-817 & $(\mathrm{CA})_{8} \mathrm{~A}$ & - & 1 & 7 & $250-2500$ \\
\hline 33 & UBC-820 & $(\mathrm{GT})_{8} \mathrm{~T}$ & - & 0 & 8 & $400-2800$ \\
\hline 34 & UBC-826 & $(\mathrm{AC})_{8} \mathrm{C}$ & - & 0 & 11 & $200-2000$ \\
\hline 35 & UBC-834 & $(\mathrm{AG})_{8} \mathrm{YT} \quad$ & - & 1 & 8 & $400-2000$ \\
\hline & & & & 13 & $1031-3000$ \\
\hline
\end{tabular}

The PCR products obtained were separated on $2 \%$ agarose gel (ICN, USA), stained with ethidium bromide $(0.001 \%)$ and documented in a gel documentation system (Hero-Lab GMBH, Germany). The size of the amplification products was estimated from 100 bp DNA ladder (Fermentas GMBH, Germany).

\section{Data analysis}

All treatments tested for the shoot cultures had at least five replicates and the data presented as an average of mean of replicates of two separate experiments with standard deviation. For both RAPD and ISSR profiles, the wellresolved and consistently reproducible fragments ranging form $200 \mathrm{bp}$ to $3.0 \mathrm{~kb}$ were scored as present or absent. For detecting any genetic change, all the RAPD and ISSR results were compared with each other for all the DNA samples.

\section{RESULTS AND DISCUSSION}

True-to-type clonal fidelity is one of the most important prerequisites in the micropropagation of any crop species. A major problem encountered with the in vitro culture is the presence of somaclonal variation amongst sub-clones of one parental line, arising as a direct consequence of in vitro culture of plant cells, tissues or organs. A better analysis of genetic stability of plantlets can be made by using a combination of two types of markers which amplify different regions of the genome (Martins et al. 2004). Palombi and Damiano (2002) suggested the use of more than one DNA amplification technique as advantageous in evaluating somaclonal variation while working on micropropagated plants of kiwi fruit. Hence, in the present study, two PCR based techniques, RAPD and ISSR were adopted for evaluation of clonal fidelity of banana plantlets. PCR - based techniques such as RAPD, ISSR, and AFLP have been found immensely useful in establishing the genetic stability of cultivated as well as in vitro regenerated plants such as Prunus dulcis (Martins et al. 2004), apple (Modgil et al. 2005), Pinus thunbergii (Goto et al. 1998), cauliflower (Leroy et al. 2001) and Digitalis obscura (Gavida et al. 1996). Cultures of Anigozanthos viridis (Turner et al. 2001) and Foeniculum vulgare (Bennici et al. 2004) that were kept under cryo-preservation, where the latter is known to cause high variation and instability due to long-term exposure to extreme conditions, the PCR-based techniques unequivocally proved to be useful for establishing the genetic stability.

In the present study, DNA extraction by GenElute ${ }^{\mathrm{TM}}$ Plant Genomic DNA Mini prep kit from Sigma (USA) resulted in the preparation of DNA samples of good quality and quantity in comparison to CTAB method that was tested primarily. Also the conditions of PCR amplification such as magnesium chloride, template DNA, Taq-polymerase concentration and annealing temperature were different and most crucial for each primer. The method used for standardizing the annealing temperature by calculating the

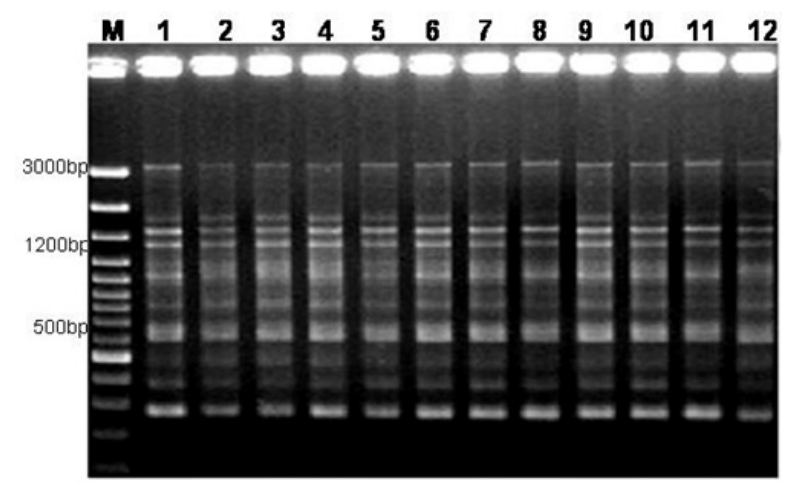

Figure 2. Randomly Amplified Polymorphic DNA (RAPD) amplification pattern obtained for mother plant (lane 1) and long-term micropropagated shoot cultures (lanes 2-12) generated by primer OPJ 09. M: GeneRuler 100 bp DNA Ladder Plus. 


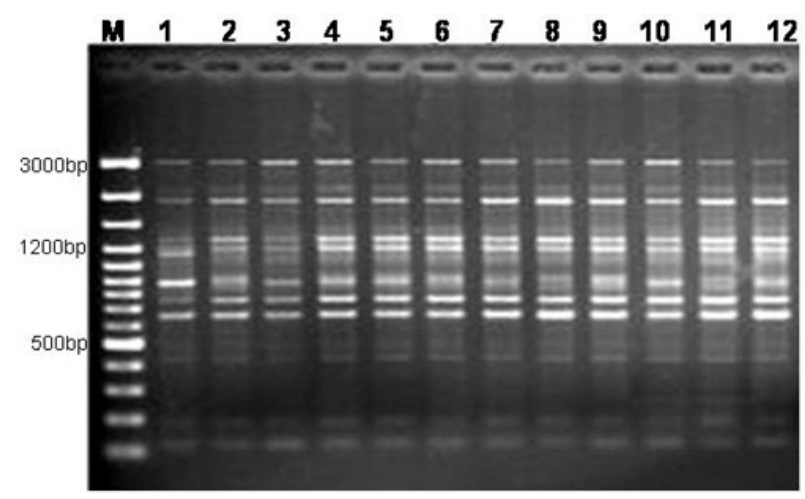

Figure 3. Randomly Amplified Polymorphic DNA (RAPD) amplification pattern obtained for mother plant (lane 1) and long-term micropropagated shoot cultures (lanes 2-12) generated by primer OPN 10. M: GeneRuler ${ }^{\text {TM }} 100$ bp DNA Ladder Plus.

melting point $\left(\mathrm{T}_{\mathrm{M}}=4(\mathrm{G}+\mathrm{C})+2(\mathrm{~A}+\mathrm{T})^{\circ} \mathrm{C}\right)$ of primers and the selection of $2^{\circ} \mathrm{C}$ lesser than the $\mathrm{T}_{\mathrm{M}}$ appeared suitable.

In order to confirm the genetic fidelity a comparison of RAPD and ISSR patterns of 11 plants chosen from 4000plus plantlets (Figure 1) and a control plant (mother plant) was carried out. Of the 50 arbitrary RAPD primers initially screened, 30 produced clear and scorable amplification products. The 30 RAPD primers resulted in 377 scorable band classes, ranging from $200 \mathrm{bp}$ to $3100 \mathrm{bp}$ in size. The number of bands for each primer varied from 6 (OPJ 08) to 22 (OPM 20) with an average of 12.6 bands per RAPD primer (Table 2). The screening with 5 ISSR primers generated 47 scorable band classes, ranging in size from $200 \mathrm{bp}$ to $2200 \mathrm{bp}$. The number of bands for each primer varied from 7 (UBC 811) to 13 (UBC 834) with an average of 9.4 bands per ISSR primer. A total of 5088 bands (numbers of plantlets analysed $\mathrm{x}$ number of band classes with all the ISSR and RAPD primers) were generated, giving rise to monomorphic patterns across all the plantlets analysed. Samples of the monomorphic band classes obtained for RAPD (Figure 2 and Figure 3) and ISSR (Figure 4) markers are shown. No polymorphic bands were observed.

Reliable monitoring of variability in DNA sequences of plants has been achieved using PCR based molecular markers like RAPD, SSR, ISSR and AFLP. Absence of genetic variation using RAPD has been reported in several cases such as micropropagated shoots of Pinus thunbergii (Goto et al. 1998), axillary bud proliferation of chestnut root stock hybrids (Carvalho et al. 2004) and almond plantlets (Martins, 2004). In contrast, somaclonal variations were reported in micropropagated plants of Pinus tremuloides (Rahman and Rajora, 2001) and Actinidia deliciosa (Palombi and Damiano, 2002) using PCR based RAPD and ISSR markers.

Dwarf somaclonal variants in in vitro cultures of banana var. Williams (Cavendish banana), have been reported
(Israeli et al. 1996) and such dwarf somaclones were relatively stable and did not generally revert to a normal phenotype (Ramage et al. 2004). It has been reported in Musa that the extent of instability caused by in vitro culture was related to cultivar rather than the culture condition (Ray et al. 2006). Whereas, in plantain, Krikorian et al. (1993) reported that frequency of variants in a certain cultivar was confined to individual primary explant rather than clones, where same chimeric heterogeneity of the primary explant was retained (Reuveni and Israeli, 1990). Another common undesirable somaclonal variant is the mosaic type heterogeneity and such an incident of variation was reported in Cavendish banana (Reuveni and Israeli, 1990). Thus the observations made in various studies indicate that variability can occur within the clone, different explants within a plant, inter-clonal and inter-varietal.

In the present study, we adopted the use of two PCR-based techniques, RAPD and ISSR, for the identification of somaclonal variation of in NR banana plantlets because of their simplicity and cost-effectiveness. The use of two types of markers, which amplify different regions of the genome, allows better chances for identification of genetic variation in the plantlets. Although this study has not detected any genetic change, it is possible that some changes might have occurred that go undetected as there is a possibility of point mutations occurring outside of the priming sites.

The exact cause of somaclonal variation in in vitro cultures are still unknown, although it is believed that alterations in auxin-cytokinin concentrations and their ratio, duration of in vitro culture, in vitro stress due to unnatural conditions, altered diurnal rhythm and nutritional conditions (Modgil et al. 2005) together or independently are responsible. Cultured plant tissues are also known to undergo high levels of oxidative stress due to reactive oxygen species formed within the cells and the latter is known to cause DNA damage, including that of microsatellite instability (Jackson et al. 1998). Probably due to some of such

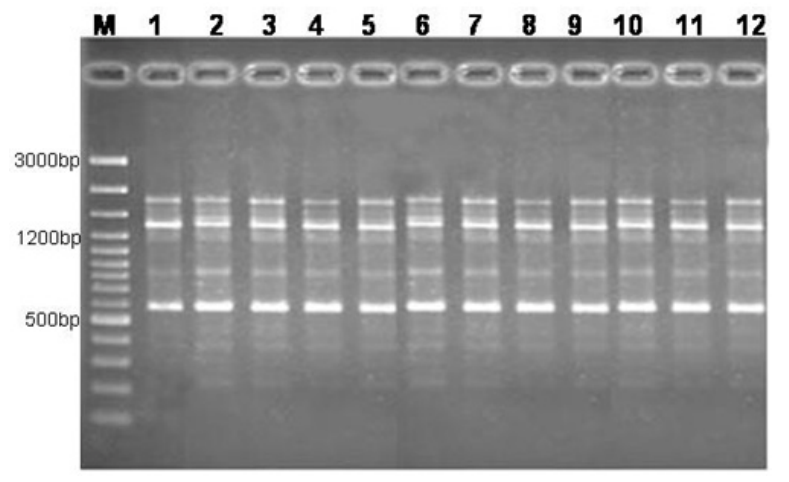

Figure 4. Inter Small Sequence Repeats (ISSR) amplification pattern obtained for DNA of mother plant (lane 1) and long-term micropropagated shoot cultures (lanes 2-12) generated by primer UBC 811. M: GeneRuler ${ }^{\mathrm{TM}}$ 100 bp DNA Ladder Plus. 
reasons, morphological variations have been a common feature as long as the shoot/plantlet cultures are under in vitro conditions, with reversal to normal state when such plantlets are transferred to soil. Development of different morphotypes during prolonged in vitro culturing was also observed by Goto et al. 1998 and Ishii et al. 1987 while working on micropropagated morphotypes of Pinus thunbergii and Pinus radiata respectively. In these studies, as well as in several other studies, the use of cytokinins, especially the exposure to BAP coupled with altered diurnal rhythm and continuous availability of high levels of nutrients have been noted to induce hyper-hydricity and alterations in morphology. Hyper-hydricity, otherwise known as vitrification phenomenon, has also been prevalent in xerophytic plants. Such morphological changes, however, were found un-associated with the genetic change (Goto et al. 1998), as also observed in NR banana of the present study. Even at post-transcriptional level, the absence of any change in isozyme patterns in such morphological off-type plants (Ishii et al. 1987) indicates that there could be temporaryalterations in the physiological states of the shoots. Therefore, even in the case of NR banana, though certain morphotypes were observed during routine multiplication, the tissue culture protocol developed by us resulted in clonal plantlets with no detectable genetic change.

In conclusion, this study has screened a large number of random primers that are common for higher plants, and some of them are prevalent in monocots. Since there were no changes in the banding pattern observed in tissue culture plants as compared with that of mother plant, we conclude that that our micropropagation protocol for banana var. Nanjanagudu Rasabale can be carried out for a considerable length of time without much risk of genetic instability.

\section{REFERENCES}

BENNICI, Andrea; ANZIDEI, Maria and VENDRAMIN, Giovanni G. Genetic stability and uniformity of Foeniculum vulgare Mill. regenerated plants through organogenesis and somatic embryogenesis. Plant Science, January 2004, vol. 166, no. 1, p. 221-227.

BHAGYALAKSHMI, N. and SINGH, N.S. Role of liquid versus agar-gelled media in mass propagation and ex vitro survival in bananas. Plant Cell, Tissue and Organ Culture, April 1995, vol. 41, no. 1, p. 71-73.

CARVALHO, Luísa C.; GOULAO, Luís; OLIVEIRA, Cristina; GONÇALVES, José Carlos and AMANCIO, Sara. RAPD assessment for identification of clonal identity and genetic stability of in vitro propagated chestnut hybrids. Plant Cell, Tissue and Organ Culture, April 2004, vol. 77 , no. 1, p. 23-27.

FAO. FAO Production Yearbook, 2003. Food and Agriculture Organization of the United, New York, vol. 57, 2004. 340 p. ISBN 9250052162.
GAVIDA, Isabel; AGUDO, Lucas del Castillo and PÉREZBERMÚDEZ, Pedro. Selection and long-term cultures of high-yielding Digitalis obscura plants: RAPD markers for analysis of genetic stability. Plant Science, December 1996, vol. 121, no. 2, p. 197-205.

GOTO, S.; THAKUR, R.C. and ISHII, K. Determination of genetic stability in long-term micropropagated shoots of Pinus thunbergii Parl. using RAPD markers. Plant Cell Reports, December 1998, vol. 18, no. 3-4, p. 193-197.

ISRAELI, Yair; BEN-BASSAT, Dahlia and REUVENI, Oded. Selection of stable banana clones which do not produce dwarf somaclonal variants during in vitro culture. Scientia Horticulturae, December 1996, vol. 67, no. 3-4, p. 197-205.

ISHII, K.; MORAN, G.F.; BELL, J.C. and HARTNEY, V. Genetic stability examination of micropropagated radiata pine (Pinus radiata) using isozyme assays. Journal of Japanese Forest Society, 1987, vol. 69, no. 12, p. 487-488.

JACKSON Aimee, L.; RU, Chen and LAWRENCE, Loeb A. Induction of Microsatellite instability by oxidative DNA damage. Proceedings of the National Academy of Sciences of the United States of America, October 1998, vol. 95, no. 21, p. 12468-12473.

KRIKORIAN, A.D.; IRIZARRY, H.; CRONAUERMITRA, S.S. and RIVERA, E. Clonal fidelity and variation in plantain (Musa AAB) regenerated from vegetative stem and floral axis tips in vitro. Annals of Botany, June 1993, vol. 71, no. 6, p. 519-535.

LEROY, X.J.; LEON, K.; HILY, J.M.; CHAUMEIL, P. and BRANCHARD, M. Detection of in vitro cultureinduced instability through inter-simple sequence repeat analysis. Theoretical and Applied Genetics, May 2001, vol. 102, no. 6-7, p. 885-891.

MARTIN, K.P.; PACHATHUNDIKANDI, S.K.; ZHANG, C.-L.; SLATER, A. and MADASSERY, J. RAPD analysis of a variant of banana (Musa sp.) cv. Grande naine and its propagation via shoot tip culture. In Vitro Cellular and Development Biology - Plant, March-April 2006, vol. 42, no. 2, p. 188-192.

MARTINS, M.; SARMENTO, D. and OLIVEIRA, M.M. Genetic stability of micropropagated almond plantlets as assessed by RAPD and ISSR markers. Plant Cell Reports, December 2004, vol. 23, no. 7, p. 492-496.

MODGIL, M.; MAHAJAN, K.; CHAKRABARTI, S.K.; SHARMA, D.R. and SOBTI, R.C. Molecular analysis of genetic stability in micropropagated apple rootstock MM106. Scientia Horticulturae, March 2005, vol. 104, no. 2, p. 151-160.

MURASHIGE, T. and SKOOG, F. A revised medium for rapid growth and bioassays with tobacco tissue culture. 
Physiologia Plantarum, October 1962, vol. 15, no. 43, p. 473-497.

NOVAK, E.J.; AFZA, R.; VAN DUREN, M.; PEREADALLOS, M.; CONGER, B.V. and XIAOLANG, T. Somatic embryogenesis and plant regeneration in suspension cultures of dessert (AA and AAA) and cooking (ABB) bananas (Musa spp.). Bio/Technology, February 1989, vol. 7, no. 2, p. 154-159.

PALOMBI, M.A. and DAMIANO, C. Comparison between RAPD and SSR molecular markers in detecting genetic variation in kiwifruit (Actinidia deliciosa A. Chev). Plant Cell Reports, May 2002, vol. 20, no. 11, p. 1061-1066.

PRADEEP REDDY, M.; SARLA, N. and SIDDIQ, E.A. Inter simple sequence repeat (ISSR) polymorphism and its application in plant breeding. Euphytica, November 2002, vol. 128 , no. 1 , p. 9-17.

RAHMAN, M.H. and RAJORA, O.P. Microsatellite DNA somaclonal variation in micropropagated trembling aspen (Populus tremuloides). Plant Cell Reports, September 2001, vol. 20, no. 6, p. 531-536.

RAMAGE, C.M.; BORDA, A.M.; HAMILL, S.D. and SMITH, M.K. A simplified PCR test for early detection of dwarf off-types in micropropagated Cavendish banana (Musa spp. AAA). Scientia Horticulturae, December 2004, vol. 103, no. 1, p. 145-151.

RAY, Tui; DUTTA, Indrajit; SAHA, Prasenjit; DAS, Sampa and ROY, S.C. Genetic stability of three economically important micropropagated banana (Musa spp.) cultivars of lower Indo-Gangetic plains, as assessed by RAPD and ISSR markers. Plant Cell, Tissue and Organ Culture, April 2006, vol. 85, no. 1, p. 11-21.

REUVENI, O. and ISRAELI, Y. Measures to reduce somaclonal variation in in vitro propagated bananas. Acta Horticulturae, July 1990, vol. 275, no. 1-2, p. 307-313.

TURNER, Shane; KRAUSS, Siegfried L.; BUNN, Eric; SENARATNA, Tissa; DIXON, Kingsley; TAN, Beng and TOUCHELL, Darren. Genetic fidelity and viability of Anigozanthos viridis following tissue culture, cold storage and cryo-preservation. Plant Science, November 2001, vol. 161, no. 6, p. 1099-1106.

VENKATACHALAM, L.; THIMMARAJU, R.; SREEDHAR, R.V. and BHAGYALAKSHMI, N. Direct shoot and cormlet regeneration from leaf explants of "silk" banana (AAB). In Vitro Cellular and Development Biology - Plant, May-June 2006, vol. 42, no. 3, p. 262-269.

WILLIAMS, John G.K.; KUBELIK, Anne R.; LIVAK, Kenneth J.; RAFALSKI, J. Antoni and TINGEY, Scott V. DNA polymorphisms amplified by arbitrary primers are useful as genetic markers. Nucleic Acids Research, November 1990, vol. 18, no. 22, p. 65. 